\title{
LIGHT TRAPPING AS A DEPENDENT OF MOONLIGHT AND CLOUDS
}

\author{
NOWINSZKY, L. ${ }^{1}{ }^{*}$ - PUSKÁS, J. ${ }^{1}-$ KÚTI, Zs. ${ }^{2}$ \\ ${ }^{1}$ University of West-Hungary Savaria Campus \\ H-9701 Szombathely Károlyi G. Square 4. \\ ${ }^{2}$ Corvinus University of Budapest \\ 1118 Budapest, Villányi Street 29-43. \\ *Corresponding author \\ e-mail: lnowinszky@gmail.com \\ (Received $26^{\text {th }}$ July 2010 ; accepted $10^{\text {th }}$ September 2010 )
}

\begin{abstract}
We examined in our study the theoretical catching distance and the catching results of the Járfás and Jermy type light-traps in the function of the moon phases and the clouds. The clouds determine the theoretical catching distances of both the Járfás and Jermy type light-traps fundamentally. The ratio of theoretical catching distances of completely overcast and clear sky is approximately 2.4:1. This difference does not appear however in the catching results. The catching of Turnip Moth (Agrotis segetum Den. et Schiff.) in moonless hours is the most successful when the sky is totally through, if it is not raining. In opposition to this, the catch decreases by the increase of the cloud cover in moonlit hours. The most moths were found in the light-trap when the sky was almost clear. The increase of cloud cover results in a reduction of the catch. The number of the Macrolepidoptera individuals and species are higher when the sky is clear than overcast in the event both the all and low clouds. It was also found that the height of cloud base also modify the light-trap catch. If the cloud base is low the light-trap catch is also low, in the opposite it is high.
\end{abstract}

Keywords: Light-trap, moon phases, clouds, catching distance

\section{Introduction}

Most of the authors experienced a drop in the efficiency of trapping as a result of moonlight. According to (Williams, 1936) the reasons for a smaller catch at a Full Moon might be as follows: Moonlight reduces the activity of insects and so the active population accessible for the light trap is smaller, or the light of the lamp collects moths from a smaller area in moonlit environment.

The researchers' opinion differs, some of them ascribe the smaller catching distance, others ascribe the moderate trapping result which can be experienced at the time of the Full Moon to the reduced activity. Some researchers take the role of the clouds into consideration. The cloud cover moderates the obstructive effect of the moonlight according to more researchers.

The clouds and the moonlight joint effect were already studied by (Williams, 1936). To examine the influence of cloud (Williams, 1936) divide the nights in the lunar months in two ways.

- In accordance with the lunar month: nights during the week of Full Moon, nights during the weeks intermediate moon (first- and Last Quarters) and nights during the week of New Moon.

- In accordance with the clouds: as regards the state of the sky, into three divisions: nights with more than $90 \%$ of the sky clear (=clear), nights with 10 - 
$90 \%$ of the sky clear (= intermediate) and nights with more than $90 \%$ cloudy (= cloudy).

The interrelation of these two main divisions gives nine possible combinations as follows:

- Full Moon - clear, Full Moon - intermediate, Full Moon - cloudy

- First- and Last Quarters - clear, First- and Last Quarters - intermediate, Firstand Last Quarters - cloudy

- New Moon - clear, New Moon - intermediate, New Moon - cloudy.

The nights with heavy wind where eliminated from calculations.

According to (Williams, 1936) results there was a tendency for the clear to be lower than the cloudy and for the Full Moon to be lower than the New Moon. The division Full Moon - clear sky give in each case the greatest negative deviation, and the division New Moon - cloudy sky give the greatest positive deviation.

The ratio of catches in the Noctuidae is shown to be 2.7:1 when New Moon was compared to Full Moon and 11.75:1 when cloudy sky are compared with clear sky. The ratio between New Moon - cloudy and Full Moon - clear is 4:1. Finally the relation New Moon - clear sky gives larger catches than Full Moon - cloudy sky 1.35:1.

Robertson (1939) reports on similar results. The cloud and moonlight have a marked effect on the light trap catches of Tipulinae. Optimum conditions are ensured by the absence of moonlight and a complete cloud cover. By contrast the conditions of Full Moon and the absence of clouds are the least favourable for the activity. Between these extremes, there is a consistent increase in catch with the increasing absence of moon and presence of clouds. The catch under optimum conditions is eight or nine times as large as in the least favourable conditions.

Garcia (1978) worked with light-traps in Venezuela, between 1973 and 1974. The largest catches of Sphingids were during the period when the moon was waning and the least catch was during Full Moon period. The cloud cover increased the effectiveness of the catch.

Bowden (1982) described the collecting radius of three different lamps with the same illumination. He also tabulated the correction values for the codes of the 10 categories of cloud types, according to which the catch rises with the increase of cloud cover.

In southern Spain, Yela and Holyoak (1997) investigated the effects of moon-phase on activity of adult Noctuid moths using light trap for 170 nights over of 2 year period. The number of individuals caught in the light trap decreased during the Full Moon period. Increased cloud cover increased catches in light traps. Cloud cover decreases the ambient light from the moon, making the light traps more visible.

According to Butler et al. (1999), the moonlight in the absence of cloud cover reduced moth catch in blacklight traps.

The most successful light trap collections were experienced by Robert (2001) during New Moon phase or on overcast nights. Mosquitoes came to lights in greatest numbers when nights were cloudy and smaller numbers when nights were clear and the moon was bright.

According to McCormick (2006-2007) the Bogong Moths (Agrotis infusa Boisduval) migrate and fly actively under cloudy conditions and during a New Moon.

Other researchers however experienced that clouds increases the catching distance though, but does not increase the efficiency of light trapping, but indeed reduces it. 
Wéber (1959) depicted graphically the measure of a cloud cover and the number of insects caught. Unambiguously he established a contrary relationship, in other words the more the clouds covered the sky the fewer insects assembled to the light.

Edwards (1961) operated a Robinson-type UV trap during 93 nights to collect Huhu Beetle (Prinoplus reticularis Whitem, Col.:Ceramb.) in New Zealand. He describes an example in which the activity of beetles increased temporarily during Moon rise, followed by a decrease when the moon was obscured by clouds.

Járfás (1969) found that the silver Y moth (Autographa gamma L.) flight to light-trap better when there was no cloudy the sky. He observed a similar light flying on moonlit nights as well. Járfás and his colleague (Járfás and Viola, 1978, 1982) published similar statements in their later works onto the Dark Fruit-tree Tortrix (Pandemis heparana Den et Schiff.), and Pine Chafer (Polyphylla fullo L.) relevantly. Járfás (1979) experienced growing light-trap catch of codling moth (Cydia pomonella L.) when the measure of the cloud cover decreased. The light-trap caught most moths (57\%) at clear sky. The higher catching results in moonlit and clear nights are linked to the orientation of the insects presumably. Flying of moths may increase to the light-trap together with the dusk while there are free areas of a cloud cover on the sky, because to the light compass orientation the insect receives enough light. If the light compass orientation of insects becomes impossible, the insect switches to orientation an other manner. This is not the inside truck for flying onto the light. The light-trap caught about three times of European Corn Borer (Ostrinia nubilalis Hbn.) at clear sky than full cloud cover.

Cordillot (1989) reports that clouds influences the light trapping of the European Corn Borer (Ostrinia nubilalis Hbn.) unfavourably because presumably it hampers their visual orientation.

The studies discussed above show that despite several decades of research into the influence of the moonlight and clouds on light trap catch, our knowledge in this field remains insufficient.

\section{Materials}

The necessary data required to our work were calculated with our own software. This software for our earlier research (Nowinszky and Tóth, 1987) was carried out by the late astronomer György Tóth for TI 59. The software was transcribed for modern computers by assistant professor Miklós Kiss: for which we express our sincere appreciation. The software calculates the phase angle of the Moon and its position above the horizon, the illumination (lux) taking the cloud cover into consideration for any given geographical place, day and time.

All our data regarding to all and low clouds and height of cloud base related data were taken from the Annales of the Hungarian Meteorological Service. Data in these books are recorded for every $3^{\text {rd }}$ hour in okta (eighth part). We have used the value given for a given hour as well as for the subsequent two hours.

We have also processed catch data of the fractionating light trap of Kecskemét on 5722 individuals of the Turnip Moth (Agrotis segetum Den. et Schiff.). This special light trap system was designed and operated by József Járfás between 1967 and 1969 at Kecskemét-Katonatelep. The light source of the fractionating light trap consists of 3 pieces of $120 \mathrm{~cm}$ long F-33 type 40W light tubes placed above each other. Independent from the time of dusk and dawn, the trap was operated every day between 6 p.m and 04 
a.m (UT). Killing jars were changed hourly by a jar-switching mechanism. These trapped insects were identified by József Járfás.

For our research, we used the complete Macrolepidoptera material of the Jermy type light trap (Jermy, 1961) operated in the Kámon Botanical Garden in Szombathely between 1962 and 1970, including data of 3395 adult broods. The light source is a $100 \mathrm{~W}$ normal electric bulb $200 \mathrm{~cm}$ above the ground. Chloroform was used for the killing. This light-trap caught 37711 moths on 1980 nights.

\section{Methods}

First we determined the theoretical collecting distances of the Járfás- and Jermy type light-traps for the New Moon and Full Moon periods. For this test, the $5^{\text {th }}$ August 1967 (New Moon) and the $19^{\text {th }}$ August 1967 (Full Moon), dates were taken into account. We calculated the values of environmental illumination (lux) on 23 hours of both nights into attention the cloud codes. From these environmental illumination values we defined the theoretical catching distances. We compared our actual catching results with the theoretical catching distances.

The Jermy type light-trap provided one catching data for one night only. The phase angle data of the Moon was calculated for every midnight of the flight periods (UT $=0 \mathrm{~h}$ ), and - in the case of fractionating light traps - for the $30^{\text {th }}$ minute of every hour. Of the 360 phase angle degrees of the full lunar 30 phase angle divisions were established. The phase angle division including a Full Moon $\left(0^{\circ}\right.$ or $\left.360^{\circ}\right)$ and values $0 \pm 6^{\circ}$ was equated to 0 . Beginning from this group through the First Quarter until a New Moon, divisions were marked as $-1,-2,-3,-4,-5,-6,-7,-8,-9,-10,-11,-12,-13$ and -14 . The next division is \pm 15 , including the New Moon. From the Full Moon through the Last Quarter towards the New Moon divisions, were marked as 1, 2, 3, 4, 5, 6, 7, 8, 9, 10, 11, 12, 13 and 14. Each division consists of 12 degrees (Nowinszky, 2003). These phase angle divisions can be related to the four quarters of lunation as follows: Full Moon $(-2-+2)$, Last Quarter (3 - 9), New Moon (10 - -10) and First Quarter (-9 - -3). The nights and hours of the periods under examination were all classified into these phase angle divisions. We have also separated the hourly catching nights of fractionating light traps with or without moonlight.

The Jermy type light-trap supplied only one catching data nightly. Because of this in this case we calculated the data of phase angle onto the midnight (UT $=0$ hour) of every night of the swarming periods.

We have calculated the relative catch values of the number of specimens trapped by species, broods and hourly data also separately for hours with and without moonlight from the fractionating light-trap data. Relative catch (RC) is the ratio of the number of specimen caught in a given sample unit of time (1 hour or 1 night) and the average number of specimen caught in the same time unit calculated for the whole brood. If the number of the specimen trapped equals the average, the value of relative catch is: 1.Only those nights and hours were taken into consideration when the catch was successful. Our earlier research (Nowinszky, 2003), convinced us that although the Moon has an influence on the efficiency of trapping, it never makes collecting impossible.

We included the relative catch values to the codes of catching hours averaged, and then separately for the moonlit and the moonless hours, then they were represented. We have given the parameters of regression equations and significance levels. 
From the Jermy type light-trap data the nightly averages of the individuals and species catch were calculated.

We examined first around the Full Moon, First- and Last Quarter the influence of cloud for the catching. We sorted the okta codes in three groups according to the measure of the cloud cover. These are the following: clear $(0,1,2)$, intermediate $(3,4,5)$ and cloudy $(6,7,8)$. Number of individuals and species caught were sorting in okta groups, were averaged and the significance levels of differences are counted with t-test.

To the additional examinations we selected the period of the Full Moon (phase angle divisions $-2,-1,0,+1$ and +2 ) from the catch data because the Moon in $85.3 \%$ are at this time stayed above the horizon. We do not consider the catching data of the periods of New Moon when there is not measurable moonlight and the data of the First- and Last Quarters, too. Not known the insects trapping in which hour of the night happened, and not know it that the Moon stayed above the horizon then, or not. We excluded the nights on which was rain, independent of his quantity from the examination. We sorted the nightly catching average values of the individuals and species to all the clouds, okta codes belong to the 2000 metres lower clouds and the values of height of cloud base (metres). We depicted the results on graphs, granted the regression equations parameters and the significance levels.

We included the relative catch values of both examined species to the hours of the catching owing okta codes, we averaged them, then separate hours without the moonlit one and the moonlight, we depicted them.

\section{Results}

The Fig. 1 and Fig. 2 shows the theoretical catching distances of Járfás- and Jermy type light-traps in the surrounding of New Moon and Full Moon, depending on the clouds.

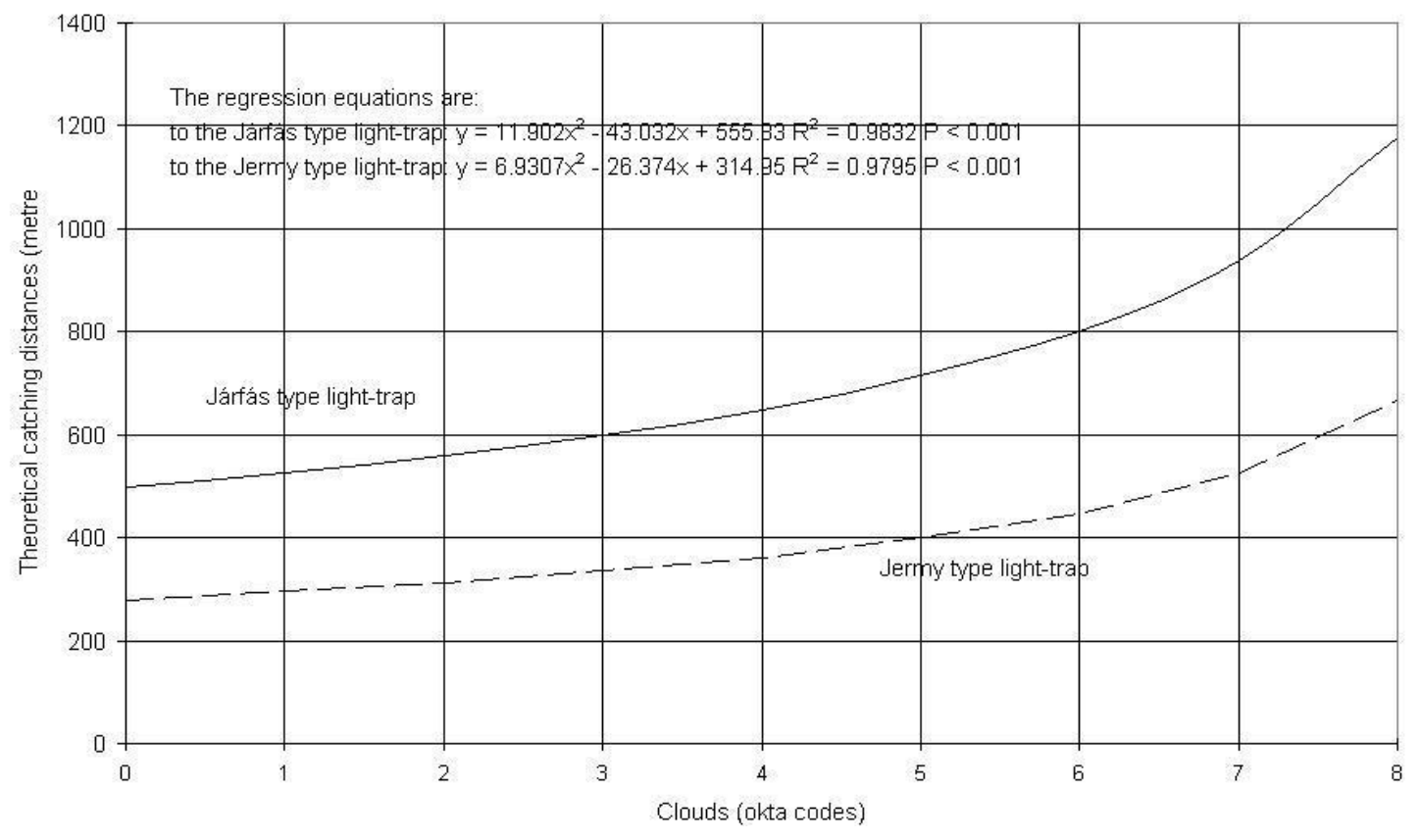

Figure 1. Theoretical catching distances of the Járfás and Jermy type light-traps depending on the clouds around the New Moon 


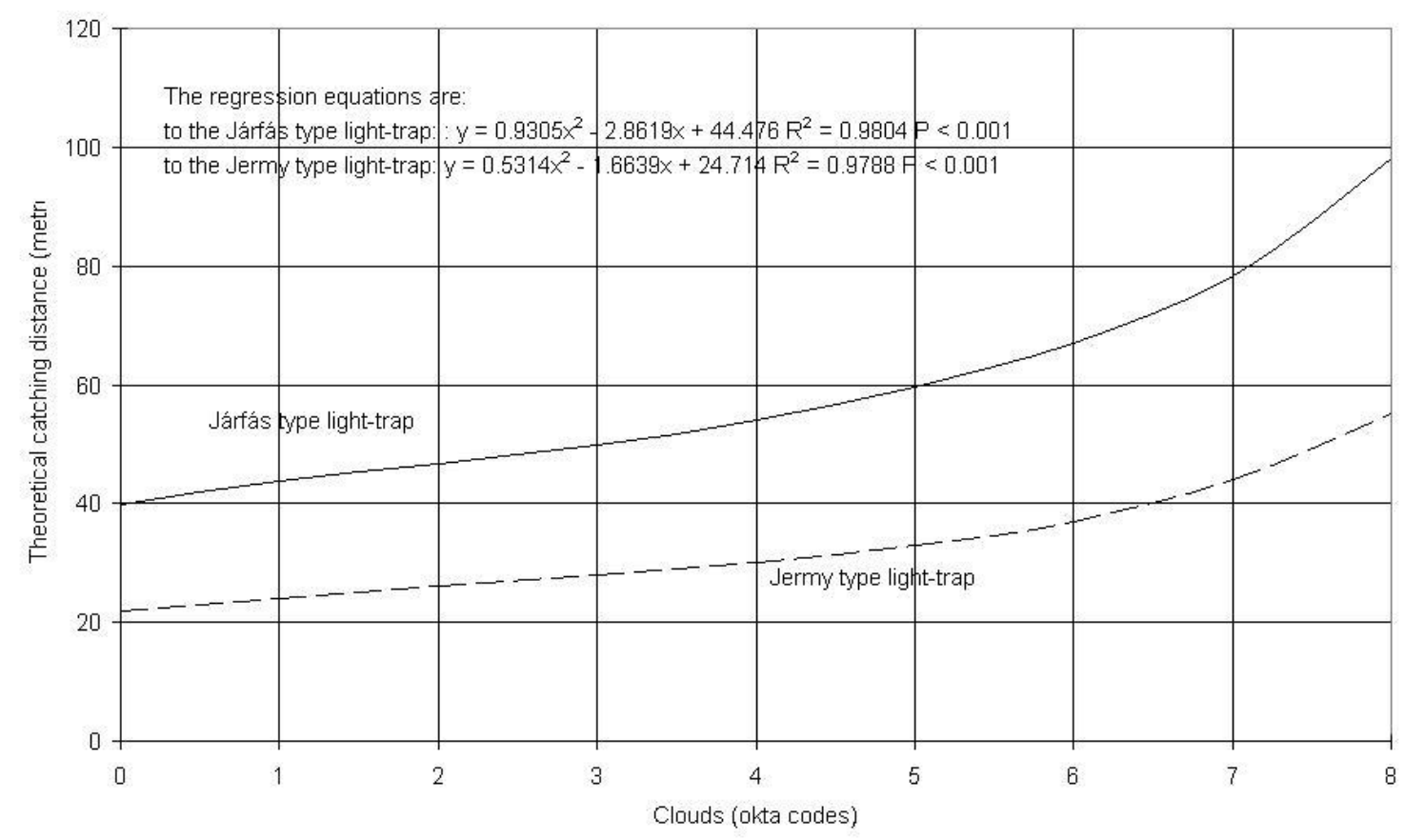

Figure 2. Theoretical catching distances of the Járfás and Jermy type light-traps depending on the clouds around the Full Moon

The catching results of the Turnip Moth (Agrotis segetum Den. et Schiff.) can be seen in Fig. 3 and Fig. 4

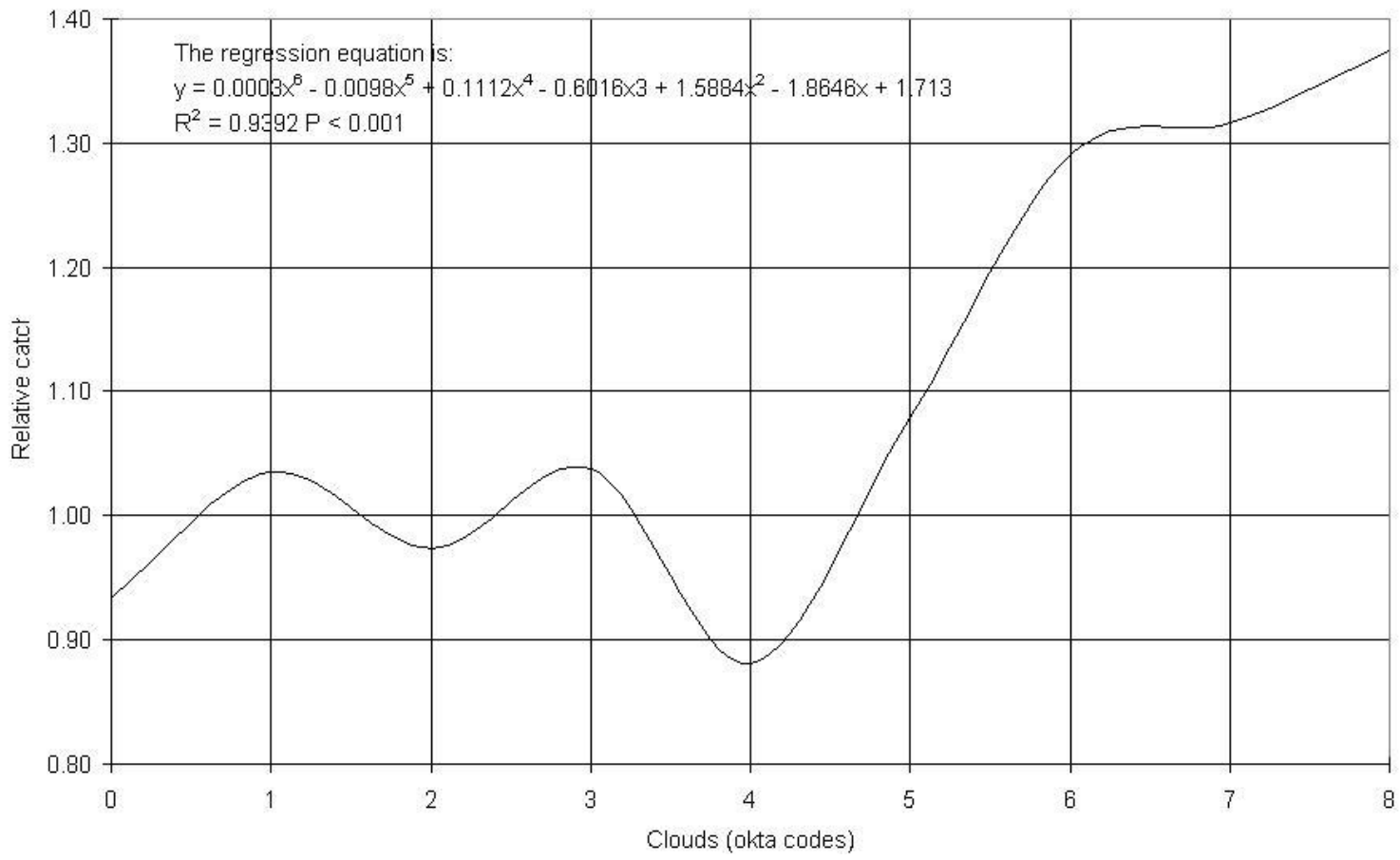

Figure 3. Light-trap catch of the Turnip Moth (Agrotis segetum Den. et Schiff.) depending on the clouds in moonless hours (Kecskemét, 1967-1969)

APPLIED ECOLOGY AND ENVIRONMENTAL RESEARCH 8(4): 301-312. http://www.ecology.uni-corvinus.hu • ISSN 15891623 (Print) • ISSN 17850037 (Online)

(c) 2010, ALÖKI Kft., Budapest, Hungary 


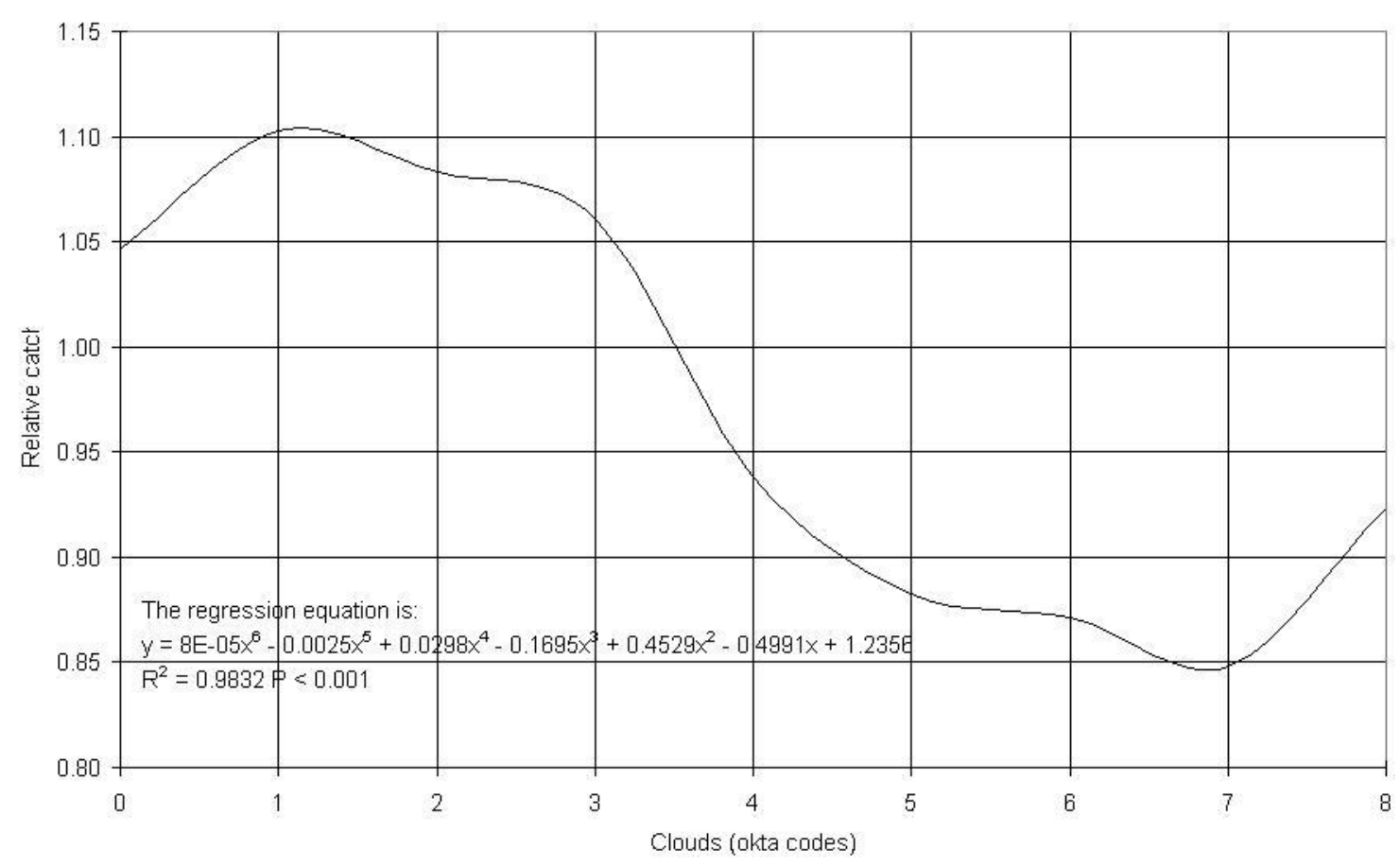

Figure 4. The light-trap catch of the Turnip Moth (Agrotis segetum Den. et Schiff.) depending on the clouds in moonlit hours (Kecskemét, 1967-1969)

The averaged numbers of individuals and species depending on the all clouds around the New Moon and Full Moon caught in Kámon Botanic Garden can be seen in Fig. 5 and Fig. 6

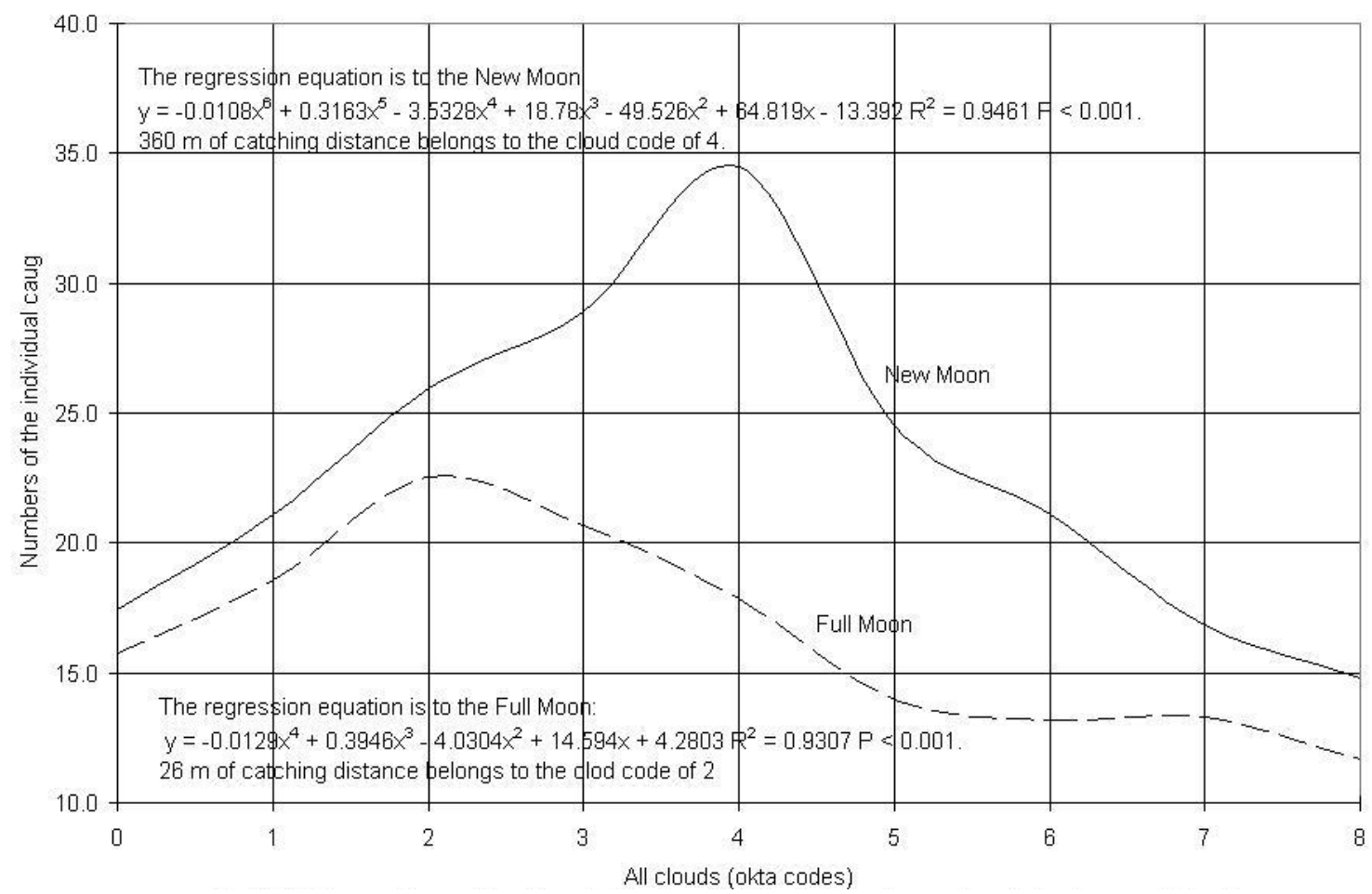

Figure 5. Light-trap catches of the Macrolepidoptera individuals depending on the all clouds around New Moon and Full Moon in the Kámon Botanic Garden between 1962 and 1970 


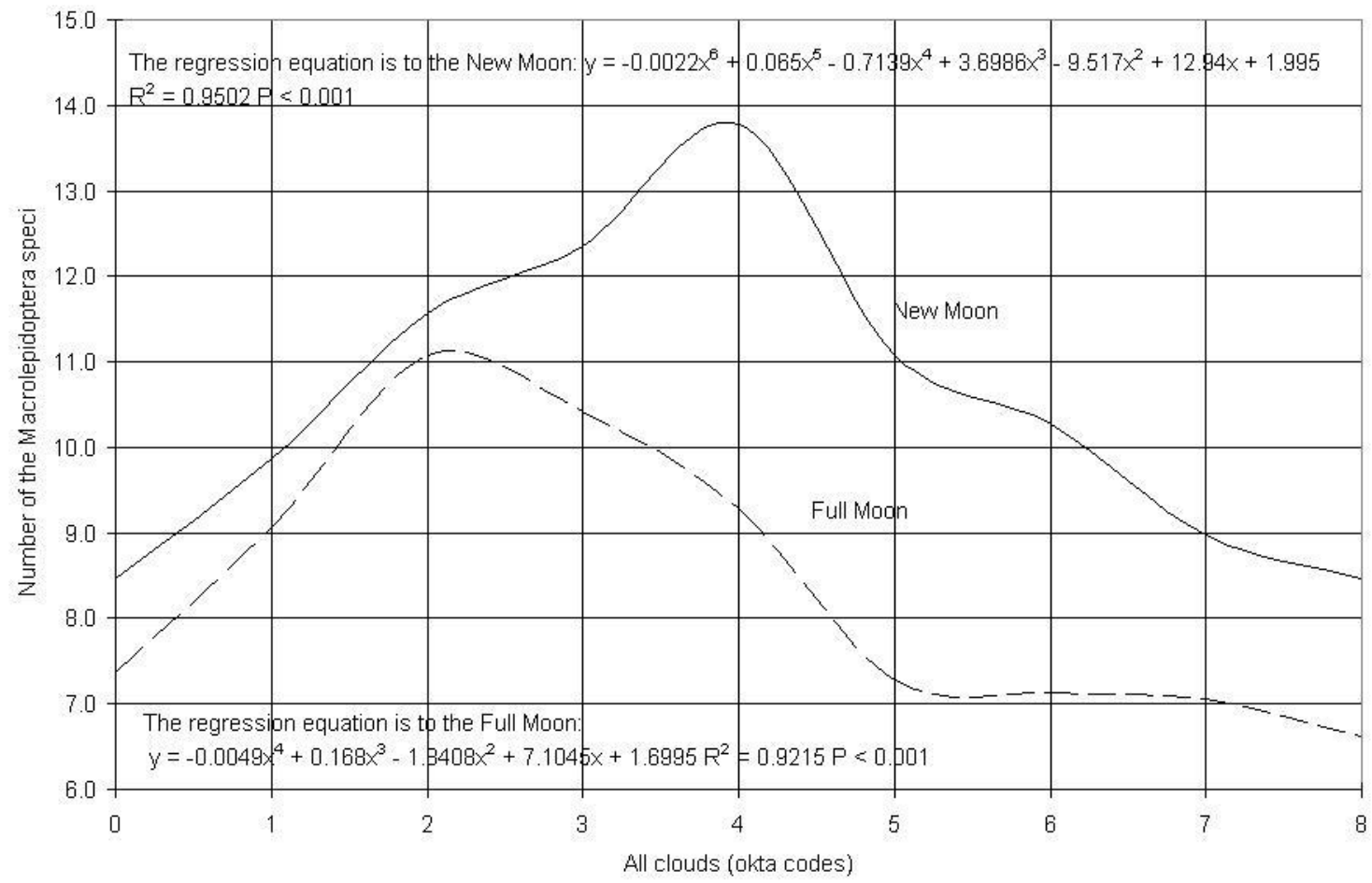

Figure 6. Light-trap catches of the Macrolepidoptera species depending on the all clouds around New Moon and Full Moon int he Kámon Botanic Garden between 1962 and 1970

Fig. 7 and Fig 8 illustrate the catching results of the individuals and species in connection with the low clouds.

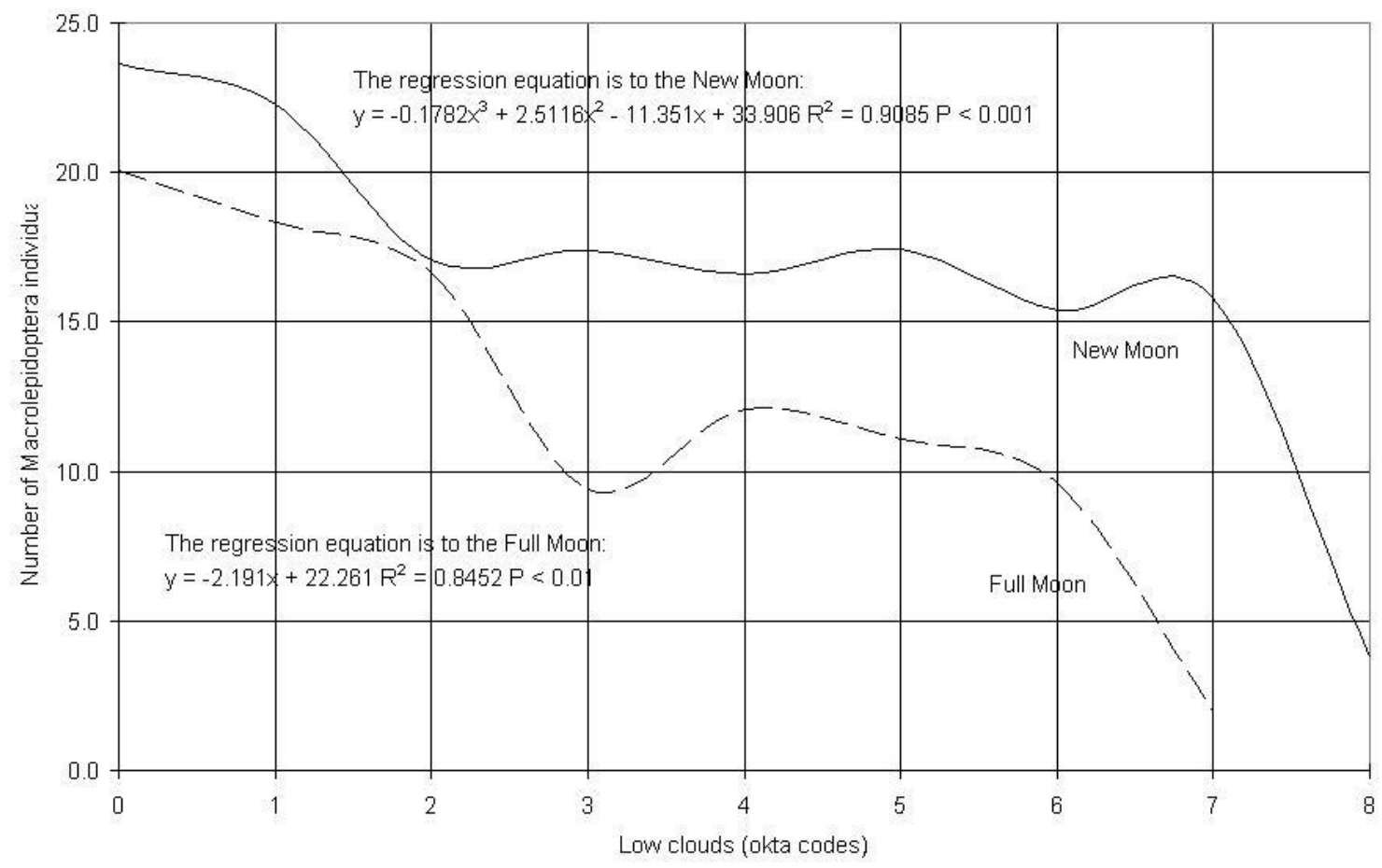

Figure 7. Light-trap catches of the Macrolepidoptera individuals depending on the low clouds around New Moon and Full Moon in Kámon Botanic Garden between 1962 and 1970 


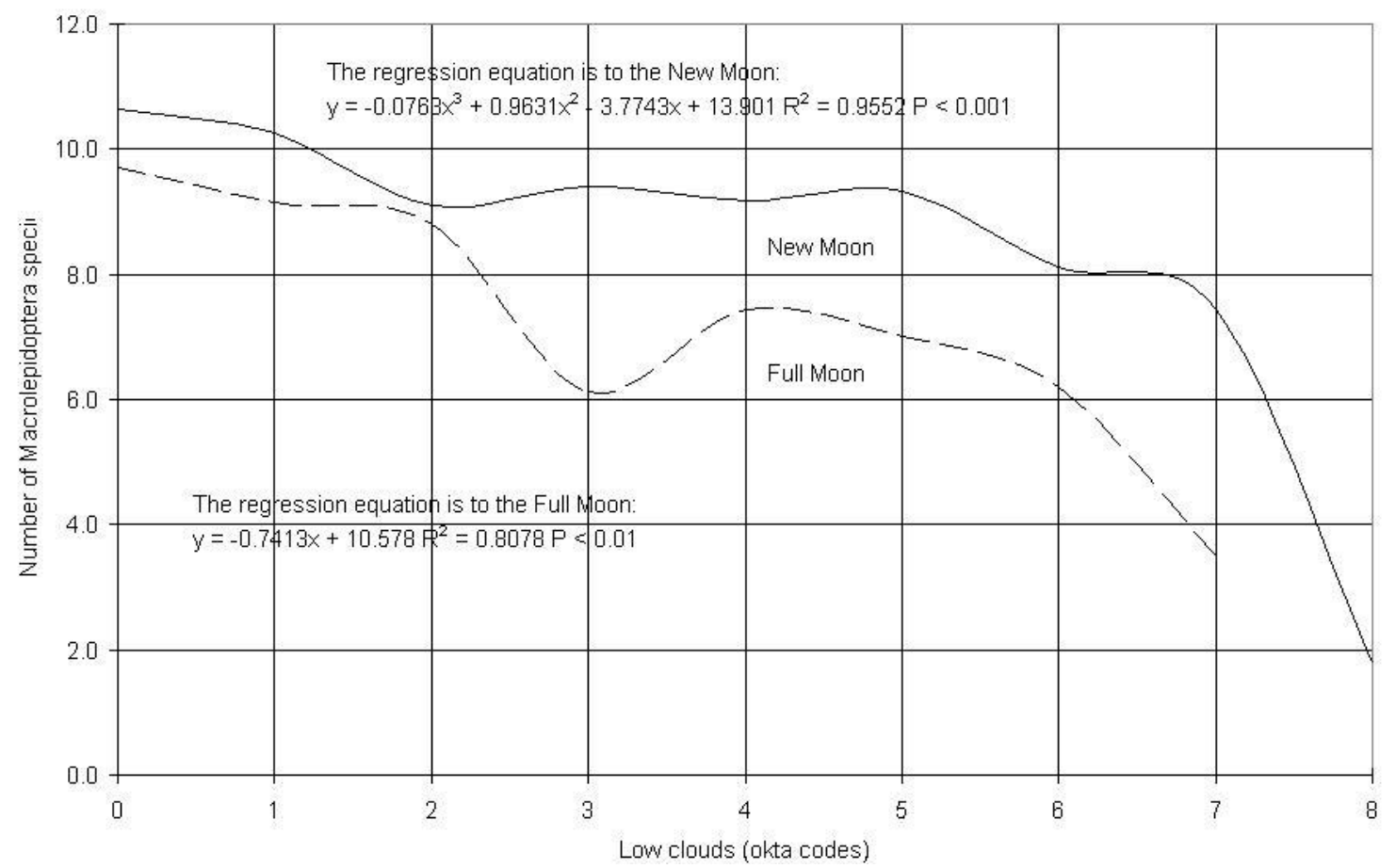

Figure 8. Light-trap catches of the Macrolepidoptera species depending on the low clouds around New Moon and Full Moon in Kámon Botanic Garden between 1962 and 1970

The Table 1 and Table 2 imply the light trapping individuals' and species' number in the function of the cloud cover, the four quarters of the Moon.

Table 1. Number of Macrolepidoptera individuals caught by light-trap in Kámon Botanic Garden in Szombathely between 1962 and 1970 depending on the moon phases and clouds

\begin{tabular}{|l|c|c|c|c|c|c|}
\hline \multirow{2}{*}{$\begin{array}{l}\text { Clouds } \\
\text { Moon phases }\end{array}$} & \multicolumn{2}{|c|}{ Clear(0-2) } & \multicolumn{2}{c|}{ Intermediate (3-5) } & \multicolumn{2}{c|}{ Cloudy (6-8) } \\
\cline { 2 - 7 } & Individuals & Data & Individuals & Data & Individuals & Data \\
\hline New Moon & 24.93 & 196 & 19.49 & 243 & 18.66 & 135 \\
\hline First Quarter & 29.48 & 118 & 17.94 & 135 & 13.37 & 87 \\
\hline Full Moon & 21.97 & 89 & 18.02 & 104 & 12.86 & 63 \\
\hline Last Quarter & 26.91 & 117 & 16.97 & 162 & 24.18 & 80 \\
\hline
\end{tabular}

Notes: Data $=$ Number of observing data. Significance levels: New Moon: Intermediate - Cloudy P < 0.05; First Quarter: Clear - Intermediate P $<0.01$, Clear - Cloudy P $<0.01$; Full Moon: Clear- Cloudy P $<0.05$; Last Quarter: Clear - Intermediate $\mathrm{P}<0.01$, Intermediate - Cloudy $\mathrm{P}<0.05$.

Table 2. Number of Macrolepidoptera species caught by light-trap in Kámon Botanic Garden in Szombathely between 1962 and 1970 depending on the moon phases and clouds

\begin{tabular}{|l|c|c|c|c|c|c|}
\hline \multirow{2}{*}{$\begin{array}{l}\text { Clouds } \\
\text { Moon phases }\end{array}$} & \multicolumn{2}{|c|}{ Clear(0-2) } & \multicolumn{2}{c|}{ Intermediate (3-5) } & \multicolumn{2}{c|}{ Cloudy (6-8) } \\
\cline { 2 - 7 } & Species & Data & Species & Data & Species & Data \\
\hline New Moon & 11.96 & 196 & 9.74 & 243 & 9.35 & 135 \\
\hline First Quarter & 13.09 & 118 & 9.27 & 135 & 7.47 & 87 \\
\hline Full Moon & 10.61 & 89 & 9.19 & 104 & 6.60 & 63 \\
\hline Last Quarter & 13.39 & 117 & 9.42 & 162 & 10.79 & 80 \\
\hline
\end{tabular}

Notes: Data $=$ Number of observing data. Significance levels: New Moon: Intermediate - Cloudy P < 0.01; First Quarter: Clear - Intermediate P $<0.01$, Clear - Cloudy P $<0.01$; Full Moon: Intermediate Cloudy P $<0.05$; Last Quarter: Clear - Intermediate $\mathrm{P}<0.01$. 
The Fig. 9 and Fig.10 show the modifying influence of the height of cloud base for the light-trap catch around the New Moon and Full Moon.

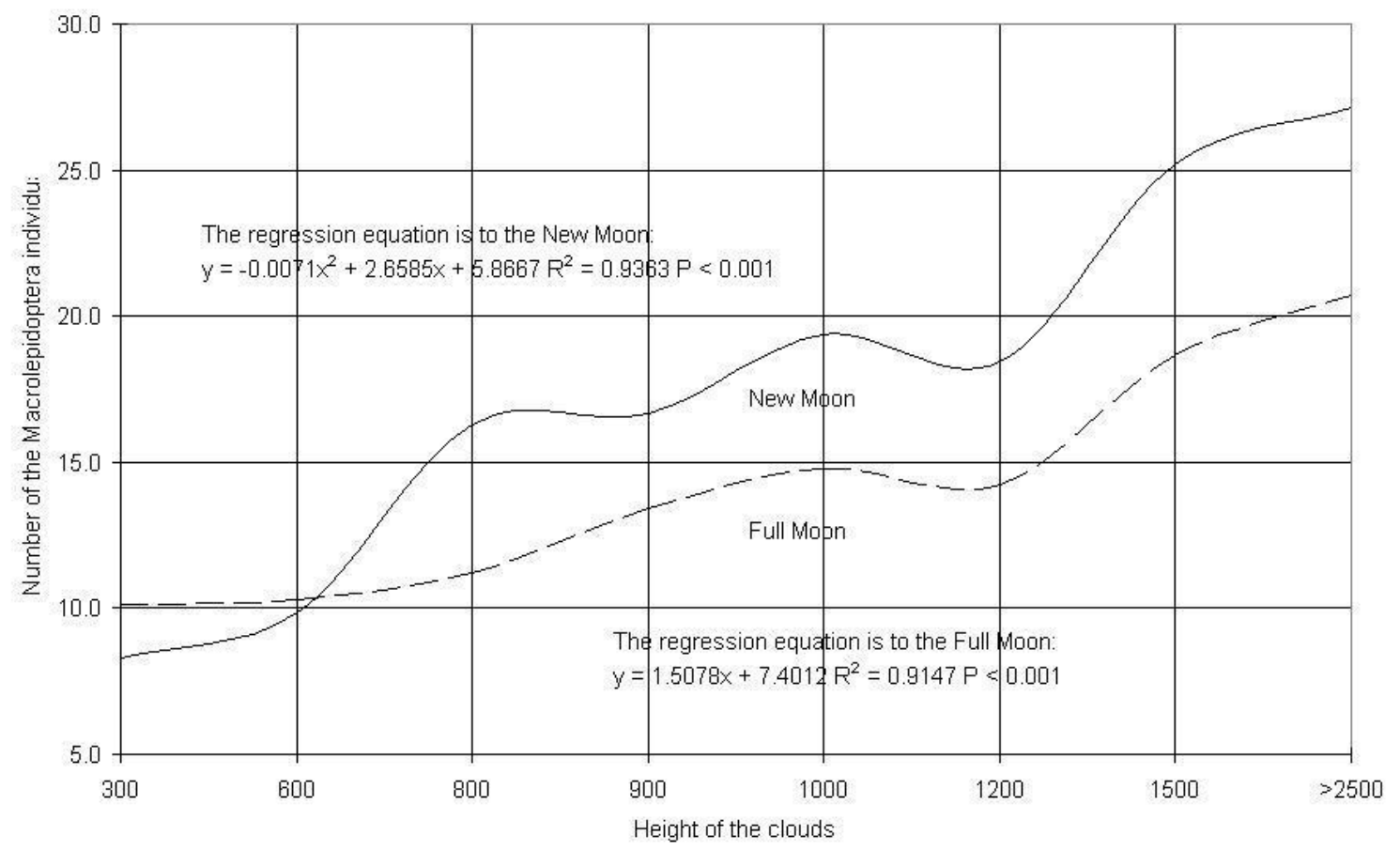

Figure 9. Light-trap catches of the Macrolepidoptera individuals depending on the height of clouds around New Moon and Full Moon in Kámon Botanic Garden between 1962 and 1970

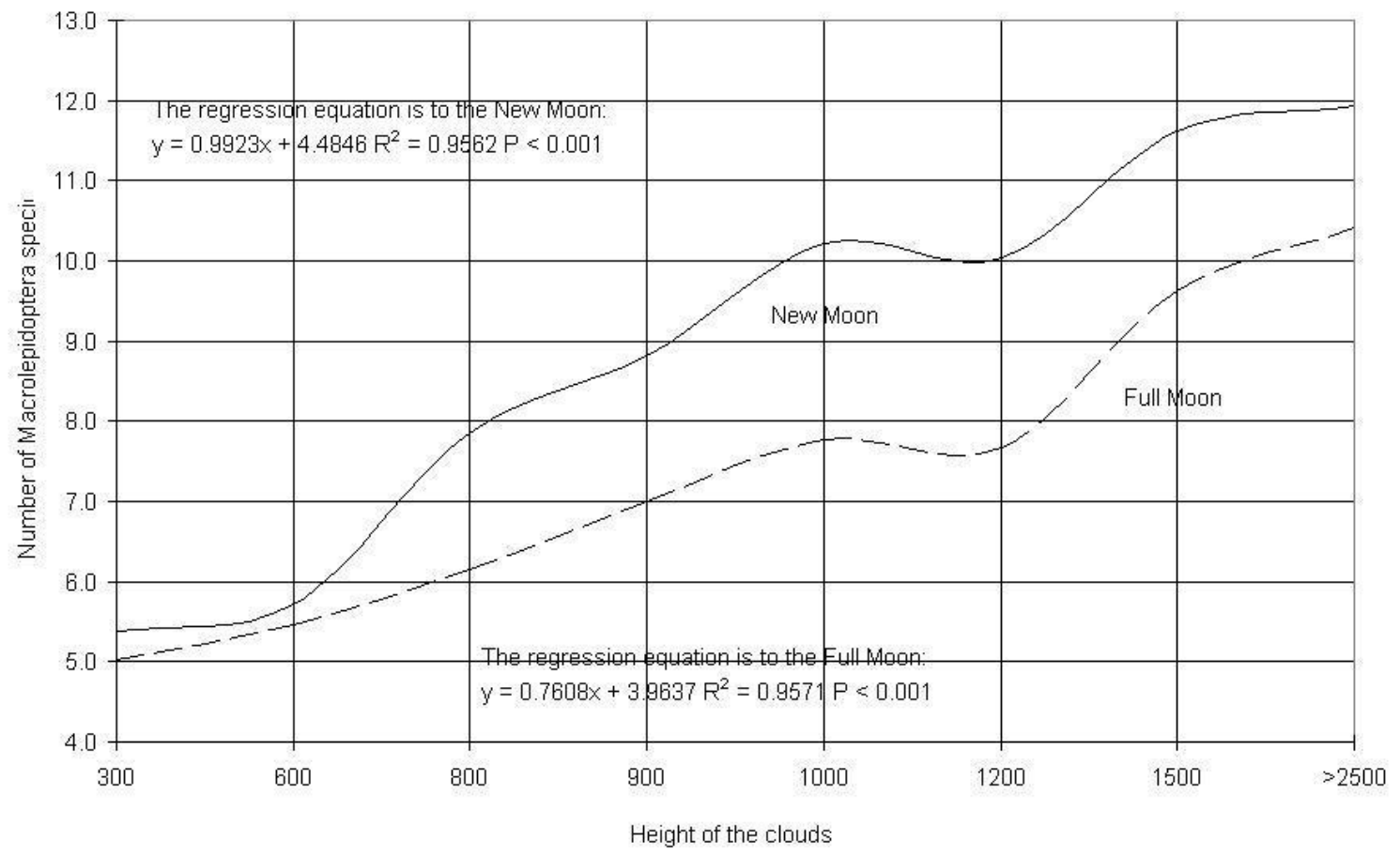

Figure 10. Light-trap catches of the Macrolepidoptera species depending on the height of clouds around New Moon and Full Moon in Kámon Botanic Garden between 1962 and 1970

APPLIED ECOLOGY AND ENVIRONMENTAL RESEARCH 8(4): 301-312. http://www.ecology.uni-corvinus.hu • ISSN 15891623 (Print) • ISSN 17850037 (Online)

(c) 2010, ALÖKI Kft., Budapest, Hungary 


\section{Discussion}

The clouds determine the theoretical catching distances of both the Járfás and Jermy type light-traps fundamentally. The ratio of theoretical catching distances of completely overcast and clear sky is approximately 2.4:1. This difference does not appear however in the catching results.

It can be verified by our examinations that the catching of Turnip Moth (Agrotis segetum Den. et Schiff.) in moonless hours is the most successful $(\mathrm{RC}=1.374)$ when the sky is totally through, if it is not raining (Fig. 3). However, if there is rain, the relative catch is only 0.518 . The difference is significant at $\mathrm{P}<0001$.

In opposition to this, the catch decreases by the increase of the cloud cover in moonlit hours (Fig. 4). The most moths were found in the light-trap when the sky was almost clear. The increase of cloud cover results in a reduction of the catch.

The explanation for this phenomenon might be that the moon will help in the insects in orientation (Nowinszky, 2008). Notice that moonlit hours have been demonstrated catches associated with fully cloud. This case occurs when the sky is clear over a part of the hour; the Moon appears, however, in different part of the hour, the sky is completely overcast, but rain does not fall.

The results shown in Fig. 5-8 also demonstrates that the number of the Macrolepidoptera individuals and species are higher when the sky is clear than overcast in the event both the all and low clouds.

Table 1 and 2 clearly show that the individuals and species caught by the Jermy type light-traps in all four moon phases are higher in bright than the overcast skies.

It was also found that the height of cloud base also modify the light-trap catch. If the cloud base is low the light-trap catch is also low, in the opposite it is high (Fig. 9 and Fig. 10).

Our examinations justify that the behaviour of single Macrolepidoptera species may be different naturally, onto the catch of most species more successful the moonlit and bright nights. Our results contradict Williams (1936) and for the results of more other researchers. In our opinion the overcast sky increased of a catching distance before with decades the number of the individuals caught may have been higher really. We deduce from our own results that the reducing effect of catching distance of the moonlight may have prevailed limitedly only because of the vegetation in the botanic garden however. Since it is the botanic garden on the city's area though, from the centre some $2 \mathrm{~km}$ extends, the urban public lighting, the neon signs and the light seeping out from the flats caused light pollution although this concept was not used yet then.

The collection distance was not significantly bigger at the time of New Moon because of this, than at the time of a Full Moon. The orientation of the moths happened based on light stimuli when the clouds did not cover the moon though; this fact increased the efficiency of the trapping. Baker (1987) and Dacke et al. (2003) proved that certain moths and beetles use for their orientation the Moon and polarized moonlight.

The catching results of a fractionating light-trap confirm the species examined orient based on light stimuli in moonlit hours and bright sky. The catch is higher because the reducing effect of a smaller catching distance with a smaller effect at this time. The longer catching distance prevailed in moonless hours for the Turnip Moth (Agrotis segetum Den. et Schiff.) In the our studies appeared recent past we established that light pollution grew in the latter decades impugn the influence of the changing of catching distance on the light trapping result (Nowinszky, 2006 and 2008). 


\section{REFERENCES}

[1] Baker, R.R. (1987): Integrated use of moon and magnetic compasses by the heart-anddart moth, Agrotis exclamationis. - Anim. Behav. 35: 94-101.

[2] Bowden, J. (1982): An analysis of factors affecting catches of insects in light-traps. Bull. ent. Res. 72: 535-556.

[3] Butler, L., Kondo, V., Barrows, E.M., Townsend, E.C. (1999): Effects of weather conditions and trap types on sampling for richness and abundance of forest Macrolepidoptera. - Environmental Entomology 28(5): 795-811.

[4] Cordillot, F.P. (1989): Dispersal, flight and oviposition strategies of the European corn borer, Ostrinia nubilalis Hbn. (Lepidoptera: Pyralidae). - A dissertation submitted to the Fac. of Sciences Univ. of Basel, Switzerland for the degree of Doctor of Nat. Sci. 134.

[5] Dacke, M., Nilsson, D.E., Scholtz, C.H., Byrne, N., Warrant, E.J. (2003): Insect orientation to polarized moonlight. - Nature 424. 33. July 03.

[6] Edwards, J.S. (1961): Observations on the Ecology and Behaviour of the Huhu Beetle, Prionoplus reticularis White. (Col. Ceramb.). - Transactions of the Royal Society of New Zealand 88(4): 733-741.

[7] Garcia, J.L. (1978): Influencia de los factores ambientales sobre la captura nocturna de Sphingidae (Lepidoptera) en Rancho Grande, Estado Aragua, Venezuela. - Revista de la Facultad de Agronomia, Universidad Central de Venezuela 9(4): 63-107.

[8] Járfás, J. (1969): Forecasting of harmful insects by light-traps (in Hungarian). - PhD Dissertation, Gödöllö, 183.

[9] Járfás, J. (1979): Forecasting of harmful moths by light-traps (in Hungarian). - PhD Thesis, Kecskemét, 127.

[10] Járfás, J., Viola, M. (1978): Effect of meteorological factors on light trapping of dark fruit-tree tortrix (Pandemis heparana Den et Schiff.) (in Hungarian). - Kertészeti Egyetem Közleményei 183-188.

[11] Járfás, J., Viola, M. (1982): Modifying intensity of weather factors for flying to the light of pine chafer (Polyphylla fullo L.) (in Hungarian). - Kertészeti E. Közleményei 215-220.

[12] Jermy, T. (1961): Monitoring insects' flight activity by light-traps (in Hungarian). A növényvédelem időszerü kérdései - Recent problems of plant protection 2: 53-61.

[13] McCormick, B. (2006-2007): Bogong moths and parliament house. - Parliament of Australia, Parliamentary Library Research Brief 6.

[14] Nowinszky, L. (2006): The light pollution and light trapping of insects (in Hungarian). Dissertationes Savarienses 36: 1-34.

[15] Nowinszky, L. [ed.] (2008): Light Trapping and the Moon. - Savaria University Press 169.

[16] Nowinszky, L. [ed.] (2003): The Handbook of Light Trapping. - Savaria Univ. Press 272.

[17] Nowinszky, L., Tóth, Gy. (1987): Influence of cosmic factors on the light-trap catches of harmful insects (in Hungarian). - PhD Dissertation, Szombathely 123.

[18] Robert, L.L. (2001): Medical Entomology Consultant to the U. S. Army Surgeon General. - Guide to Entomological Surveillance During Contingency Operations 1-158.

[19] Robertson, A.G. (1939): The nocturnal activity of Crane-Flies (Tipulinae) as indicated by captures in a light trap at Rothamsted. - The Journal of Animal Ecology 8(2): 300-322.

[20] Wéber, M. (1959): The quantity of insects caught by light-trap when is evaluated the climatic behaviours to be taken into account (in Hungarian). - Állattani Közlemények 47: 165-175.

[21] Williams, C.B. (1936): The influence of moonlight on the activity of certain nocturnal insects, particularly of the family of Noctuidae as indicated by light-trap. - Phil. Trans. Roy. Soc. London. B. 226: 357-389.

[22] Yela, J.L., Holyoak, M. (1997): Effects of moonlight and meteorological factors on light and bait trap catches of noctuid moths (Lepidoptera: Noctuidae). - Environmental Entomology 26(6): 1283-1290. 